\title{
WOE UNTO THEM THAT LAY FIELD TO FIELD: ClOSER SETTLEMENT IN THE EARLY LIBERAL ERA
}

\author{
Monique van Alphen Fyfe
}

\begin{abstract}
This article undertakes a re-examination of the origins, construction and application of the Land for Settlements legislation in the early Liberal era. The Liberal's commitment to closer settlement reveals part of the story of highly contested land policy in colonial New Zealand. Land for Settlements legislation of the 1890s, aimed at "bursting up" the great estates, was predominantly the product of settlers' ideological aspirations and two determined politicians: John Ballance and John McKenzie. When measured against the rhetoric used to promote it, however, the policy was not necessarily effective: it was complicated by practical realities and a narrow vision of New Zealand as a vigorous Arcadian paradise. When contrasted with the treatment of Māori land, yet more of the complexity of the land issue and the frailties of the actors facing it are revealed. The article concludes by proposing that Liberal policy, while flawed in execution, may have nevertheless contributed something to the consolidation of the concept of New Zealand as an agrarian ideal, a concept that remains largely intact today.
\end{abstract}

\section{INTRODUCING AN IDEOLOGY}

Ill fares the land, to hastening ills a prey; where wealth accumulates, and men decay. ${ }^{1}$

Liberal land policy has been an evocative and much examined topic for historians of decades past. The emergence of Waitangi Tribunal histories has since tended to homogenise Crown land policy such that very real shifts in government initiatives risk becoming overlooked. Land policy was, in fact, highly contested in colonial New Zealand. This article addresses the actions of a Government which is widely credited, deservedly or not, with introducing radical programmes of land reform,

* BArch(Hons). Submitted as part of the LLB(Hons) programme at Victoria University of Wellington. The author would like to extend her deepest thanks to Professor Richard Boast QC for his invaluable patience and guidance.

1 Oliver Goldsmith "The Deserted Village" (1770) as cited in (20 July 1894) 83 NZPD 653 per EM Smith MHR. 
particularly the "bursting up" of great estates. To that end, this article re-examines the detail and effect of the Liberals' early closer settlement policy to rediscover something of the complexities of the story.

First, the broad social and political themes of the era and the viewpoints of key political figures are outlined, followed by an examination of the legislation they enacted. Closer settlement was part of a myriad of legislation related to land that intended to distribute it more densely and equitably. Its particular links to land tax and tenure policies are noted. Also noted is its germination in the thinking of reforming politicians such as John Ballance and John McKenzie, whose ideologies were heavily influenced by their experiences of land issues in Ireland and Scotland respectively.

Implementation of the policy is then addressed. The much-celebrated example of Cheviot is discussed in detail, followed by a general overview in order to measure the success of the policy with reference to the rhetoric that accompanied its promulgation. Looking more broadly, the policy is then considered against the treatment of the greatest estate. The Liberal approach to Māori land is contrasted with that relating to Pākehā land, revealing yet more of the complexity of the land issue and the frailties of the actors facing it.

The article concludes by examining the proposition that Liberal policy, while flawed in execution, may have nevertheless contributed something to the consolidation of an idea of New Zealand: that it is a fair and free agrarian paradise.

\section{FOUNDATIONS FOR REFORM}

A land wherein thou shalt eat bread without scarceness. ${ }^{2}$

\section{A The State of the Colony}

The majority of the adult European population in 1890 were migrants. Their idea of New Zealand was one shaped by the promotion of the colonies as a "New World' utopia", where industriousness rather than inherited privilege would be rewarded. ${ }^{3}$ It had long been recognised that settlers were "animated by the desire of having a piece of the world they may call their own". ${ }^{4}$ Steeped in various

2 Deuteronomy 8:9 as cited in James Cowan New Zealand or Ao-Te-Roa: Its Wealth and Resources, Scenery, Travel-Routes, Spas, and Sport (New Zealand Government Department of Tourist and Health Resorts, Wellington, 1908). See also for context Miles Fairburn The Ideal Society and Its Enemies: The Foundations of Modern New Zealand Society 1850-1900 (Auckland University Press, Auckland, 1989) at 22-27 and 256.

3 David Hamer The New Zealand Liberals: The Years of Power, 1891-1912 (Auckland University Press, Auckland, 1988) at 50-53.

4 (23 August 1870) 9 NZPD 194 per Rt Hon William Fox MHR. 
shades of biblical education, settlers projected a "common desire for greater equality". ${ }^{5}$ Politicians, also so steeped, frequently saw themselves as nation builders as the words of John Ballance illustrate: 6

... we are engaged in building up - or rather laying the foundation - of a great Nation, which certainly is now one of the brightest jewels in the British Crown. A self governing country, the people of which are earnestly devoted to freedom ...

The divide between the Old and New Worlds is starkly apparent in the land debate. As David Hackett Fischer notes: ${ }^{7}$

Land had a double importance in setter societies. It was arguably the most important instrument for the shaping of a social order. At the same time, it was perceived as the primary way to individual wealth. These two purposes were often at odds, increasingly so.

Fears that Old World class systems were replicating themselves in New Zealand are amply illustrated by parliamentary debates. ${ }^{8}$ Land, the principal source of livelihood and security - and thus freedom was seen as becoming concentrated in the hands of the few. Even more affronting, this land often sat idle. Politicians claimed New Zealand, an assumed tabula rasa, had an opportunity to set a different path. By providing solutions to these Old World problems, as a "social laboratory of the world" New Zealand had an opportunity to establish its national identity. ${ }^{9}$

Land, or access to it, was considered the cause of and answer to many contemporary problems. It was of particular concern in the South Island, especially Canterbury and Otago, where vast estates were common and there was little surplus Crown land and virtually no Māori land left into which to expand. Without it, southern farmers feared their sons would be forced to migrate to the North Island or Australia. ${ }^{10}$ Settlers in the North Island, too, complained of a lack of land, but the monopolisers

5 Tom Brooking "Use it or Lose it: Unravelling the Land Debate in Late Nineteenth-Century New Zealand" (1996) 30 NZJH 141 at 148.

6 John Ballance MHR private correspondence as cited in Hamer, above n 3, at 53, n 63. See also David Hackett Fischer Freedom and Fairness: A History of Two Open Societies, New Zealand and the United States (Oxford University Press, Oxford, 2012) at 306-307; and John Stenhouse "God's own silence: secular nationalism, Christianity and the writing of New Zealand history" (2004) 38 NZHJ 52.

7 Fischer, above n 6, at 153 (citations omitted).

8 See for example (26 August 1891) 74 NZPD 80; (10 August 1892) 76 NZPD 603; and (10 October 1895) 91 NZPD 279 per Hon John McKenzie MHR.

9 Hamer, above n 3, at 59-61.

10 Tom Brooking Lands for the People? The Highland Clearances and the Colonisation of New Zealand: A Biography of John McKenzie (University of Otago, Dunedin, 1996) at 80; and JS Duncan "The Land for the People" in Murray McCaskill (ed) Land and Livelihood: Essays in Honour of George Jobberns (New Zealand Geographical Society, Christchurch, 1962) 170 at 177-180. 
were Māori. ${ }^{11}$ Across the country, lack of land was seen as contributing to unemployment and population pressure in towns. ${ }^{12}$ Urbanisation was viewed as inferior to and less productive than rural living. ${ }^{13}$ Policy to reverse this trend was generally welcomed. Land reform was thus considered by many Liberals to be the foremost of all political questions, of universal significance and the universal solution. ${ }^{14}$

The land question manifested itself in growing hostility towards land banking, landlordism and owner absenteeism. Settlers wanted to own land to achieve independence and raise their prospects, but also, as Miles Fairburn suggests, to connect with the land in a way perceived as interrupted by the industrial revolution. ${ }^{15}$ Given that in 1888 one per cent of landowners owned 64 per cent of available freehold land, ${ }^{16}$ this was an impossible dream. If the 1880 s had been the decade of runholders and monopoly, the following decade promised to be very different.

New Zealand in 1890 was in the throes of recovering from prolonged economic depression. Large landowners had generally escaped unscathed, but smaller farmers struggled immensely. The increasing monopoly in land ownership combined with a reluctance to sell at depressed prices was locking smaller farmers out. ${ }^{17}$ Compounding this were the unsavoury tactics of grid-ironing (buying up attractive pockets and leaving others inaccessible or unprofitable) and dummyism (buying land in the name of another to circumvent statutory limits). These circumstances began to shape questions: what amount of land was enough, who ought to own it, and under what terms? Tom Brooking summarises it thus: "The land debate was ... about the hard issues of paying off debt, productivity, monopoly of wealth, and political power, as well as softer and more sentimental issues. "18

The debate raging behind this was one of tenure: which of freehold or leasehold ought to be dominant in this New World? Passion ignited either side. Hardline leaseholders, who tended to be urbanites, argued such tenure would enable more settlers to obtain land at fairer prices. Long fixed leases also offered more security than freehold because the latter was subject to reclamation at any

11 See generally Tom Brooking "'Bursting Up' The Greatest Estate of All: Liberal Maori Land Policy, 18911911" (1992) 26 NZJH 78; and Richard Boast Buying the Land, Selling the Land: Governments and Maori Land in the North Island 1856-1921 (Victoria University Press, Wellington, 2008) at 183.

12 See Hamer, above n 3, at 150-194.

13 Brooking, above n 5, at 145-146.

14 (10 July 1891) 72 NZPD 127 per Rt Hon John balance MHR; and see Hamer, above n 3, at 65-68.

15 Fairburn, above n 2, at 19-73.

16 J Sperrey "Return of Owners of 5,000-Acre Blocks and Upwards Showing Absentee Owners, Banks, and Individual Owners" [1890] I AJHR H22A.

17 Brooking, above $\mathrm{n}$ 5, at 142 .

18 Brooking, above n 10 , at 80 . 
time by the Crown or, indeed, mortgagees. Furthermore, if such land was leased from a benevolent landlord - which only the State could be - the ensuing fair rental would free up capital for improvements. ${ }^{19}$ Freeholders, on the other hand, generally argued for choice of tenure. The few hardliners, who tended to be large landholders, viewed leasehold with suspicion. They not only feared rent increases by stealth, but also argued settlers had emigrated in order to gain freehold, not leasehold. ${ }^{20}$ Land tenure policy was thus integrally linked to closer settlement.

Besides Māori land tenures, up to 1891 New Zealand enjoyed several principal types of tenure: freehold, agricultural leases, ${ }^{21}$ deferred payment licences, ${ }^{22} 30$-year perpetual leases with rights of purchase introduced by William Rolleston in $1882,{ }^{23}$ small grazing runs established by John Ballance in 1885 for small sheep farmers, ${ }^{24}$ and special and village settlements. ${ }^{25}$ Various experiments with these latter tenures had been attempted with little success. ${ }^{26}$

Throughout the Liberal era other tenures were added. Firstly, cash purchases were discouraged by limiting the available acreage and preventing title being issued until improvement requirements were met. ${ }^{27}$ Leases in perpetuity, a peculiar political compromise, replaced perpetual leases and ran for 999 years without rent reappraisals, but were also subject to strict improvement requirements. ${ }^{28}$ Occupation with right of purchase provided a 25 -year lease, with purchase rights available after 10 years, also subject to improvements. ${ }^{29}$ In 1907 , renewable leases finally replaced leases in perpetuity. ${ }^{30}$ The complexity of these options is palpable. Proprietors of large estates often held land under a mixture of freehold and leasehold. Within that seemingly simple distinction, types of tenure

19 At $88-89$.

20 At $92-93$

21 Gold Fields Act 1862, s 35.

22 Otago Wastelands Act 1872, s 47.

23 Land Act 1877 Amendment Act 1882

24 Land Act 1885, ss 197-291.

25 Sections $162-168$.

26 Henry George Progress and Poverty (Doubleday, New York, 1879) at 98-99 and 130-134 as cited in Timothy McIvor The Rainmaker: A Biography of John Ballance 1839-1893 (Heinemann Reed, Auckland, 1989) at 110

27 Land Act 1892 , ss 139 and 148.

28 Sections 141, 144 and 157-161.

29 Sections 141, 144 and 152

30 Land Laws Amendment Act 1907, ss 3-6. 
were something of a motley assembly that reflected their origins in political compromise due to disunity on the issue, even within the Liberal faction.

These later tenure options were largely thanks to the matrix of land legislation introduced from 1892 as a means to effect closer settlement of the land. Instead of clarifying or consolidating tenure, closer settlement contributed to its complexity.

Closer settlement policy was, in essence, to encourage the breaking up of large areas of sparsely populated land into smaller estates supporting a denser farming population. It was believed that this would simultaneously solve landlessness, unemployment and urban overpopulation. It was broadly supported by settlers throughout the colony, including many conservatives and large landholders. ${ }^{31}$ Communal operation of land, such as that practiced by Māori, was not favoured. "[P]rogress and civilisation" was associated not with uninhabited bush but with "well-tilled fields". ${ }^{32}$

Associated with this was a question of who ought to benefit from increases in land value due to public works. Recent railway extensions had significantly increased the value of some estates, and unsuccessful legislative attempts were made to recover this "unearned increment" for the State. ${ }^{33}$ The work of Henry George was considered by some Liberals as a better solution. George proposed a single tax on unimproved land which would force development or divestment of unproductive land. ${ }^{34}$ Land divested to the State could be rented on periodic review. Taxation and rent would thus return to the State increases in land value for which it was mostly responsible.

Within this context, politicians attempted to position themselves for the 1890 general election, fought predominantly on the issue of land reform.

\section{$B$ The Positions of Ballance and McKenzie}

The 1890 general election might be called a watershed moment for New Zealand political history. Whereas 1887 is noted for what Keith Sinclair suggests was the emergence of nationwide political groups that might become parties, ${ }^{35} 1890$ saw control of the Executive relocate to a group of men who, in one arrangement or another, would hold the balance of power for almost 22 years. Of these men, two in particular were of paramount importance in relation to the production of early Liberal land policy: John Ballance and John "Jock" McKenzie.

31 Brooking, above $\mathrm{n} 10$, at $80-81$.

32 At 81 and generally at $97-130$.

33 Railways Improved Lands Bill 1883.

34 McIvor, above n 26, at 234 and 286-289.

35 K Sinclair "The significance of 'the Scarecrow Ministry', 1887-1891" in Robert Chapman and Keith Sinclair (eds) Studies of a Small Democracy: Essays in Honour of Willis Airey (University of Auckland, Auckland, 1963) 102. 
Ballance, Premier from 1891 until his death in early 1893, had emigrated from Ireland via Birmingham, finally settling in Whanganui in 1866. The son of a tenant farmer, Ballance himself had little interest in working the land and instead became the proprietor of several successful newspapers. ${ }^{36}$ Upon becoming Premier, he was one of the few North Islanders holding any of the powerful Cabinet positions. He had form for radical land policy. As Minister of Lands from 1884 to 1887, he saw land settlement as a part of the solution to devastating unemployment and undesirable urban drift. ${ }^{37}$ In introducing the Bill that would become the Land Act 1885 he noted: ${ }^{38}$

... the best of all kinds of bonafide settlement is that which enables the State to retain control over the

land, and which enable the people who want land to cultivate and not for speculative purposes to go onto

the land and hold it.

For the purpose of settlement, there was, he said, "nothing in the world which will compare with the system of perpetual leasing". 39 The Land Act established new forms of settlement including smallholdings (for part-time labourers near cities), special settlements, land grazing and village homestead special settlements. ${ }^{40}$ In promoting a wide range of settlement options, Ballance was interested in achieving equitable interdependence between town and country.

After returning to the opposition bench in 1887, he reprinted earlier articles on land reform in which he predicted the "'freehold sentiment' will die away in the presence of hard logic and facts", ${ }^{41}$ to the benefit of the "cultivator of the soil, rather than the speculator". ${ }^{42}$ Ballance was well-read, citing the likes of JS Mill and Henry George in his articles and speeches. These two in particular provided the intellectual foundation he desired in support of his idea that the problems colonial New Zealand faced lay in the land. Combining the ideas of Mill and George, his was ostensibly a "complete theory of prosperity and stability". ${ }^{43}$

Recovering the unearned increment was a method to discourage landlordism and absenteeism by depressing capital gains. He took care to emphasise that smallholdings would not be affected; rather his targets were large estates, particularly those of absentee or idle owners. His desire was to limit

36 McIvor, above n 26, at 20-23.

37 At 129 .

38 (16 July 1885) 52 NZPD 45.

39 (16 July 1885) 52 NZPD 45

40 Land Act 1885, ss 162-168 and 197-291.

41 John Ballance A national land policy based on the principle of state ownership: with the regulations of the village homestead system (Lyon and Blair Printers, Wellington, 1887) at 3.

42 At 4.

43 McIvor, above n 26, at 110. 
landholding to 2,000 acres, which (betraying his northern perspective) might have worked for North Island beef or dairy farms, but not for southern sheep runs. ${ }^{44}$ The justification of the tax was twofold: the moral right to take that which an owner has not earned, and fairness in expecting those who enjoy more privileges to contribute accordingly. ${ }^{45}$

His aim for land nationalisation was a separate goal, with slightly different justifications: ${ }^{46}$

... the principal reason in favour of the nationalization of the land is that the land of any country soon becomes a monopoly, the possessors being few in comparison with the population. The monopolists without effort grow rich. The landless, continually increasing their number, grow poor ... Let us suppose, now, that we have only national land. The phenomena presented in this case would be, on the one hand a body of cultivators paying rent, to the State; and on the other a greater body living by wages, mainly in towns, deriving a beneficial interest from the rents, and remaining content in the knowledge that they participate in the prosperity of the agricultural tenant.

Wealth, he argued, stems from the land and also benefits urban dwellers. Only the equitable distribution of land via nationalisation would meet the demands of the settler population and guarantee a measure of equality, security and political stability. ${ }^{47} \mathrm{He}$ went so far as to claim the previous economic depression was a result of land monopoly and poor administration of underutilised government land. ${ }^{48}$ Moreover, land nationalisation promoted democratic principles: it benefitted the many rather than the few and encouraged more individualistic use of the land. ${ }^{49}$

Ballance was both more and less radical than his intellectual sources. He never sought to implement a flat single tax, but instead combined a graduated tax with nationalisation to create a tempered solution in response to the mood of the electorate. His programme was revived, albeit somewhat revised, by McKenzie in 1891.

McKenzie was the Minister of Lands from 1891 to 1900. Born in the parish of Rosskeen in Ross and Cromarty, Scotland, in 1839, he immigrated to New Zealand in 1860 and become a moderately successful farmer near Palmerston. His character was coloured by a deep sense of moral responsibility, illustrated by his acknowledging (and thus legitimising in Scottish custom) a child born

\footnotetext{
44 At 114 .

45 Ballance, above $\mathrm{n} 41$, at 17-18.

46 At 8 .

47 At 8; and McIvor, above n 26, at 111.

48 "Mr Ballance at the Gaiety Theatre" The Hawke's Bay Herald (Napier, 31 October 1889) at 3. See also McIvor, above $\mathrm{n} 26$, at 162 .

49 John Ballance as cited in McIvor, above n 26, at 113.
} 
to him out of wedlock during his teenage years.$^{50}$ Like Ballance, his strong moral position was heavily influenced by experiences of substantial inequality in his home country.

The Scottish Highland Clearances were a traumatic period of tenural upheaval, forced eviction and cultural dislocation that lasted for over 100 years. ${ }^{51}$ A five-year-old McKenzie witnessed disturbing scenes of the effects of one of the Clearances' most acrimonious episodes. Ninety people, including many children, had taken shelter in rudimentary tents set up in a graveyard; they had nowhere to go but the place used as refuge by only the most desperate of criminals. ${ }^{52} \mathrm{He}$ had seen, he claimed, the ground tilled to hide the blood of those who attempted to protect their homes. ${ }^{53}$ Although his own family never suffered eviction, he later married Ann Munro whose family had. ${ }^{54}$ The experience, reinforced by the culture of the Free Church to which he belonged, cemented a belief in the dangers of extravagant landlordism that he would carry with him while shaping land policy in the New World.

His expertise and passion was in land, and he knew it. Entering Parliament in 1881 he shrewdly delayed his maiden speech until 1882 to respond to Rolleston's Land Bill, a tactic that earned him the status of a backbencher to watch. ${ }^{55}$ His later speech in closing debate on his own Land Bill referred in emotional terms to his Scottish encounter: 56

The Minister of Lands, Sir, got his ideas as a boy when he saw the poor people evicted from their houses in the most cruel manner, and unable to get a place for their feet to stand upon ... they went to the cemeteries. The poor people were not even allowed to camp upon the King's highway. The only place in the world where they could go and rest themselves without being put in gaol was among the dead in the cemetery. I have seen that in my days. Is it any wonder that I should have opinions of my own in connection with the land question in this country?

50 Brooking, above n 10, at 25-26.

51 See for example Alexander Mackenzie The history of the Highland clearances (2nd ed, Stirling, Eneas Mackay, 1914); John Prebble The Highland Clearances (Penguin Books, London, 1963); and Eric Richards A history of the Highland clearances: agrarian transformation and the evictions, 1746-1886 (Croom Helm, London, 1982).

52 Brooking, above n 10, at 15-16.

53 (26 August 1891) 74 NZPD 80.

54 Brooking, above n 10, at 16.

55 (14 July 1882) 42 NZPD 341-343. See also Brooking, above n 10, at 59.

56 (10 August 1892) 76 NZPD 603. 
Whatever later revisionists might have to say about the true causes and justifications for the clearances, Brooking concludes McKenzie's views were drawn primarily on moral rather than economic considerations, and these underlined his justifications for legislative reform. ${ }^{57}$

He led two Committees of Inquiry into land in 1885 and 1890. Neither had significant impact on the practice of grid-ironing or dummyism, but they did enhance McKenzie's focus on the great estates and raise his profile such that he became something of an "emerging 'land specialist"'. ${ }^{5} \mathrm{He}$ employed accusations of political corruption and favouritism to consolidate his foundation as a battler for the little people. ${ }^{59}$

Not obviously driven by intellectual theories, McKenzie instead built principles based on his own personal and industry experiences. In Rosskeen, successful farmers operated on larger blocks; smaller ones advocated for by urban radicals tended to lock farmers into poverty and dependency. McKenzie's experience of New Zealand reinforced this: his own fortunes turned largely upon the acquisition of larger land holdings. ${ }^{60} \mathrm{He}$ brought to Liberal policy a practicality alongside his lifelong passionate desire to make the Scottish experience an impossibility in the New World.

The combination of the intellectual theories and pragmatism of Ballance and the relentless determination and farming experience of McKenzie are perhaps the reason Liberal closer settlement policy is best characterised not as radical or pure, but as a mingling of ideology and practicality.

\section{CONSTRUCTING AN IDEOLOGY}

Woe unto them that join house to house, that lay field to field, till there be no place, that they may be placed alone in the midst of the earth. ${ }^{61}$

\section{A The Legislative Framework}

Closer settlement was not the product of a single piece of legislation. Although the policy is primarily associated with the various Land for Settlements Acts and their amendments, one of the policy's most illustrious demonstrations was the result of entirely different legislation: the Land and Income Assessment Act 1891. Further, the revised Land Act of 1892 set the parameters for the types of tenure available for the disposal of Crown land. Ultimately, the policy was given definitive

57 Brooking, above n 10, at 18 .

58 At 61-63.

59 At 63-64.

60 At $33-38$.

61 Isaiah 5:8. This verse was well known at the time, particularly by those of Scottish extraction, and was employed several times in parliamentary debates. See for context Brooking, above n 10, at 83 and n 35 . 
manifestation in the Land for Settlements Acts, which granted significant executive powers to obtain and exploit land for closer settlement.

\section{The Land and Income Assessment Act 1891}

The Land and Income Assessment Act 1891 (LIAA) was Ballance's tool to implement his graduated version of a Georgian land tax. Ballance sought to tweak the market to incentivise smaller landholdings and thus increase equality of ownership. The 1881 Property Assessment Act that the LIAA replaced contained provisions to compel the Government to buy and dispose of land subject to disputed tax valuations; but these were fiscal, not social in their purpose. ${ }^{62}$ These provisions were continued in the LIAA for the "protection of the revenue", again fiscally focused over any social aim. ${ }^{63}$

Because the LIAA instigated a graduated land tax on unimproved land, owners were incentivised to place value on improvements to minimise tax obligations and government valuers the opposite to maximise tax intake. This, combined with s 31 of the LIAA that allowed owners to initiate the buyback provisions, foreshadowed that large runholders might undercook their valuations to take advantage of a government buyer in a stagnant market. No one, not even Ballance, envisaged this ${ }^{64}$ the anticipated beneficiaries of s 31 were owners of smallholdings unable to meet tax obligations.

Some larger landowners were worried. The graduated tax would have a significant impact on the income of large mortgaged properties, rendering some arrangements financially unsound. ${ }^{65}$ Nevertheless, it was less financial strife and more a family disagreement that brought about the most conspicuous use of these provisions: the Cheviot estate purchase discussed below.

A landholder's ability to initiate buyback was not addressed until the Act and its amendments were consolidated in 1900, which removed the buyback provisions entirely. ${ }^{66}$ This suggests that even though it was in a sense used against them, the Government was not overly concerned about such exposure.

62 Property Assessment Amendment Act 1881, ss 13 and 14.

63 Land and Income Assessment Act 1891, ss 30 and 31.

64 WJ Gardner A Pastoral Kingdom Divided Cheviot, 1889-1894 (Bridget Williams Books, Wellington, 1992) at 98

65 G Stead "The Chamber of Commerce: The Taxation Proposal" The Press (Christchurch, 30 July 1891) at 6.

66 Land and Income Assessment Act 1900. 


\section{The Land Act 1892}

The Liberals introduced a Land Bill in 1891, but were not successful in passing anything like it into law until the following year. ${ }^{67}$ The 1891 Bill proposed to repeal the 1890 Land Act and dealt comprehensively with numerous aspects of land in the colony. McKenzie's introduction embodied the idea that New Zealand had opportunities to be better than Britain; the legislation was "a step in the right direction", "an advance as far as public opinion will allow us to go" and would: ${ }^{68}$

... assist us in drawing out ... the people from the great cities of the world, and out of the dark dens and

the dark receptacles of those cities, and will send them to the valleys and straths of the uplands where their

happy voices will sound with gladness and energy, and it will give each his full share of earth and sky.

The Bill sought to consolidate the "one man one run" principle, ${ }^{69}$ going so far as to impose imprisonment on those evading its provisions in order to emphasise that tactics such as dummyism were no better than theft. ${ }^{70}$ It also allowed the Government to acquire land and dispose of it via two new types of tenure: perpetual lease with periodic rent reappraisals (what came to be called leases in perpetuity) $;{ }^{71}$ and deferred payment (a 25 -year licence that came to be called "lands for occupation"). ${ }^{72}$ These were in addition to the existing tenures of freehold, small grazing runs, village settlements, and special settlements that the Land Bill carried over. ${ }^{73}$ The Bill was passed by the House of Representatives, but failed to gain the support of an aggressive Legislative Council despite conferences between the two. ${ }^{74}$

A second attempt, what became the Land Act of 1892, retained much of the 1891 Bill, but passed the Legislative Council only after protracted negotiations. ${ }^{75}$ Key concerns were the rent reappraisals associated with leases in perpetuity and a lack of purchasing options associated with lands for occupation. Section 157 of the enacted legislation made no reference to rent reappraisals and s 152(3) inserted an option to either purchase the freehold or exchange the licence for a lease in perpetuity after

67 There were multiple versions of the Bill: Land Bill 1891 (75-1); Land Bill 1891 (75-2); Land Bill 1891 (753); and Land Bill 1891 (75-4).

68 (21 July 1891) 72 NZPD 369-379. See also Brooking, above n 10, at 103-104.

69 Brooking, above n 10, at 102.

70 See for example Land Bill 1891 (75-1), cls 84, 85, 138, 146, 154 and 185.

71 Clause 143. Compare Land Act 1892, s 157.

72 Clause 136. Compare Land Act 1892, s 152.

73 Clause 126, and pts IV and V.

74 (22 September 1891) 74 NZPD 812, 850 and 872. See also Brooking, above n 10, at 105-106.

75 (6 October 1892) 78 NZPD 717. See also Brooking, above n 10, at 113. 
10 years of occupation. ${ }^{76}$ These changes meant the State could not preserve for itself the unearned increment, nor maintain ownership of the land. Respectively, these two factors greatly diminished the potential of the Act to serve as a tool to establish a Georgian land tax system and found leasehold as the emerging dominant land tenure. Already ideology was morphing at the hands of political reality.

\section{The Land for Settlements Act 1892}

The inaugural Land for Settlements Bill of 1891 sought to introduce a more direct mechanism than the LIAA for breaking up large estates. ${ }^{77}$ It incorporated both voluntary and compulsory takings of land deemed necessary for achieving closer settlement in areas where land was in short supply. For the purpose of "providing land for settlement", $\mathrm{cl} 4$ allowed the Governor to "contract with any owner of private land" to purchase that property, and provided the Governor with the power to "take any land" under the Public Works Act $1882 .{ }^{78}$ Compulsory taking was not without limits; for example, the site of a dwelling house (up to 2,000 acres) was not to be taken, nor was any land already precluded by the Public Works Act available for compulsory purchase. ${ }^{79}$ Any land successfully acquired could be disposed of only via perpetual lease (later leases in perpetuity), with no option to purchase the freehold ${ }^{80}$ Allotments could not exceed 320 acres. ${ }^{81}$ It was a bold move that looked a lot like involuntary land nationalisation; it called for bold justifications.

On its second reading, McKenzie focused on the right of the State to take land, the necessity of such measures and the propriety of the measures proposed ${ }^{82}$

... if large estates stand in the way of the settlement and progress of the country, we can claim the right to resume such properties on such terms as will do no injustice to the people from whom we take them.

Citing the country districts of Canterbury, Timaru and Oamaru, McKenzie noted the potential for migration should the Bill not be passed. ${ }^{83}$ Wary of the need to obtain the support of town-based Members of the House of Representatives, he sought to emphasise cities' reliance on the country for

76 Land Act 1892, ss 152(2) and 153(3). Compare Land Bill 1891 (75-1), cl 136; and Land Bill 1892 (35-4), cl 146. Small grazing runs were, however, not able to be purchased even after 10 years: Land Act 1892, s 177(a).

77 There were two version of this Bill: Land for Settlements Bill 1891 (79-1); and Land for Settlements Bill $1891(75-2)$

78 Land for Settlements Bill 1891 (79-1), cl 4(1) and (2).

79 Clause 19(2) and (3).

80 Clause 19. Compare Land for Settlements Bill 1892 (41-3), cl 16.

81 Land for Settlements Bill 1891 (79-1), cl 19.

82 (9 September 1891) 74 NZPD 437.

83 (9 September 1891) 74 NZPD 438. 
commerce and supplies to support their population. ${ }^{84}$ Mention was made of the need to capitalise on recent railway installation, which was, he claimed, wasted where it ran only through great estates. Refuting claims that the Bill was revolutionary, McKenzie asserted that concerns regarding compulsion and potential "jobbery" would be mitigated by the State restricting itself to obtaining the most appropriate land and only for the purpose of settlement. ${ }^{85}$ Finally, in addressing whether the land so obtained ought to be leased or sold outright, McKenzie pointed to the potential for any land sold outright to fall back into the great estates, thus confounding the very purpose of the Bill. ${ }^{86}$

Debate centred not so much on the more fundamental question of the State's right to take land, but on whether the time was ripe for such measures and a fear that the Minister would be inundated with offers of substandard land. Some support from the opposition - several of whom were large landowners ${ }^{87}$ - was grudgingly forthcoming, due to electorate demand and perhaps, in part, to Rolleston's previous attempts at similar if less radical measures. ${ }^{88}$

McKenzie spent much of his closing comments on his surprise at the adverse stance of Māori Members, who feared greater loss of Māori land, ${ }^{89}$ and chastising his colleagues generally for being "prepared to give to private individuals what they are not prepared to give to the Government". ${ }^{90}$ The Bill passed its third reading in the House of Representatives without trouble. ${ }^{91}$ It failed at the Legislative Council. ${ }^{92}$

Like the Land Bill, take two of the Land for Settlement legislation took place the following year. ${ }^{93}$ Despite the limitations on compulsory purchase in the earlier Bill, the contention it caused proved too onerous. Political necessity meant the revised Bill, and the Act, excluded the compulsory purchase

84 (9 September 1891) 74 NZPD 438.

85 (9 September 1891) 74 NZPD 438.

86 (9 September 1891) 74 NZPD 438.

87 See for example Sir John Hall's entry in J Sperrey "Commissioners Report: Results of Property Assessment 1888" [1890] I AJHR B15 at 23.

88 (9 September 1891) 74 NZPD 439-440. Rolleston's attempts include the Land Bill 1882; Land Bill 1883; and Railway Improved Lands Bill 1883.

89 (9 September 1891) 74 NZPD 447, 451 and 448-450.

90 (9 September 1891) 74 NZPD 454.

91 (11 September 1891) 74 NZPD 539.

92 (18 September 1891) 74 NZPD 761. See also Brooking, above n 10, at 106-108.

93 There were three versions of the Bill: Land for Settlements Bill 1892 (41-1); Land for Settlements Bill 1892 (41-2); and Land for Settlements Bill 1892 (41-3). 
provisions altogether and removed any reference to the Public Works Act $1882 .{ }^{94}$ However, the tenure for disposal remained solely leases in perpetuity, ${ }^{95}$ and maximum holdings of Land for Settlements land stayed at 320 acres. ${ }^{96}$

Despite removing the most contentious issue, debate was similarly divided and, surprisingly, more strident. Concerns were raised regarding, inter alia, financial matters, repudiation by settlers, discrepancies in rental proposals between various Acts and removing parliamentary oversight. ${ }^{97}$ These concerns, however strident, were clearly outweighed by support. One Member of the House foreshadowed the Cheviot affair, commenting favourably that such a division of the estate would "increase the prosperity of the whole district". ${ }^{98}$ Another referenced a similar Bill which was soon to be introduced in the English House of Commons, from which a desire to lead rather than follow might be inferred. ${ }^{99}$ The Land for Settlements Act 1892 (LFSA) became law by a comfortable margin in both the House of Representatives and the Legislative Council. 100

These legislative measures acted in concert, providing a complex scheme to effect closer settlement of rural land. Before the scheme coalesced, however, the Liberals were presented with a providential but risky opportunity to test-run their policy. The risk they took came to symbolise Liberal aspirations for their platform of reform.

\section{AN IDEOLOGY IN ACTION}

That the hands shall henceforth have acres, and the acres shall henceforth have hands! ${ }^{101}$

\section{A The Great Estates}

The LFSA promised land for the landless and envisaged many more settlers on many more plots of land: an agrarian paradise of self-sufficient smallholdings. While David Hamer is sceptical of claims of Liberal idealism in general, ${ }^{102}$ with respect to land they were not merely cynical pragmatists, but also idealists. However, and with the possible exception of Ballance, they were not radicals.

94 Land for Settlements Bill 1892 (41-3), cl 4; Land for Settlements Act 1892, s 4; and (16 August 1892) 77 NZPD 78. See also Brooking, above n 10, at 113.

95 Land for Settlements Bill 1892 (41-3), cl 16; and Land for Settlements Act 1892, s 16.

96 Land for Settlements Bill 1892 (41-3), cl 18; and Land for Settlements Act 1892, s 18.

97 (16 August 1892) 77 NZPD 78-91.

98 (16 August 1892) 77 NZPD 80 per William Lee Rees MHR.

99 (16 August 1892) 77 NZPD 88 per Richard Meredith MHR.

100 Brooking, above n 10, at 113.

101 AJH Duganne "The Acres and the Hands" in The Poetical Works of Augustine Duganne (Parry and McMillan, Philadelphia, 1885) 146 at 147 as cited in (1894) 84 NZPD 231-234 per Hon John McKenzie MHR.

102 See generally Hamer, above n 3 . 
Examination of the legislation instead indicates a careful if complicated restructuring of the land and economic system in tandem, with lofty goals alongside practical solutions. Its application, too, deserves close scrutiny.

The LFSA was not yet in effect when the first and most notable expression of its policy began to unfold. Cheviot, regarded as the exemplar of closer settlement policy, was not a consequence of the LFSA, but rather something of an unexpected prize in a lottery accidentally orchestrated by the LIAA buyback provisions. ${ }^{103}$

William "Ready Money" Robinson died in 1889, leaving Cheviot - his 84,000-acre Canterbury estate - on trust to five daughters. His heirs had various aspirations for Cheviot, one in particular vying for the property's sale. There were, however, few private buyers for an estate of such a scale, and the trustees advised against developing and dividing it privately. ${ }^{104}$ Under pressure from the heirs, mortgagees and the looming LIAA taxes, one of Cheviot's trustees, Francis Henry Dillon Bell, appears to have developed a strategy of forcing the Government's hand to buy the property using s $31 .{ }^{105}$ The trustees disputed the estate's government valuation using s 19, initiating the LIAA review process. ${ }^{106}$ Given the official position on large estates and the LIAA purpose of revenue protection, it was never likely that the trustees would receive a favourable outcome, thus providing them with an "impeccable" claim to invoke s $31 .{ }^{107}$

The Cabinet decision to acquire Cheviot was made between the parliamentary sessions of 1892 and 1893. The price agreed was $£ 260,220$. Such administrative action itself was not unheard of, but a "proposal of this magnitude, in such a crucial field and involving a very large sum, was without precedent". ${ }^{108}$ Tidying up the purpose of acquisition and payment for the estate, however, required parliamentary action. ${ }^{109}$ Rolleston, during one of these debates, foretold that Cheviot would become a "white elephant". ${ }^{110}$ It did not.

Ballance was initially reluctant to agree to the purchase, and the few surviving documents suggest the deal was instead championed in Cabinet by McKenzie. ${ }^{111}$ Ballance's later declarations indicate

103 Gardner, above n 64, at 113.

104 At 55 .

105 At 62; and Land and Income Assessment Act 1891, s 31

106 Land and Income Assessment Act 1891, ss 19(3) and 21.

107 Gardner, above n 64, at 63 and generally at 56-66.

108 At 109.

109 Cheviot Estate Disposition Act 1893; Cheviot County Act 1893; and Cheviot Estate Payment Act 1893.

110 (27 September 1893) 82 NZPD 791-795.

111 Gardner, above n 64, at 110-111. 
public enthusiasm may have changed his mind. ${ }^{112}$ Due to both illness and McKenzie's growing dominance, Ballance's influence on the Cheviot affair was slight. By the time Parliament reconvened to consider the matters of Cheviot's payment and divestment, Ballance had passed away. Despite this, it was his land tax legislation aimed at reducing the sizes of estates that provided McKenzie with a rather remarkable opportunity to illustrate the potential of a more extensive policy to do just that.

During 1893, Cheviot was surveyed and divided into three types of tenures under the Land Act 1892: payment for cash, grazing run leases and leases in perpetuity. Three ballots were held to allocate the land from November 1893 to May 1894. Almost all the land was disposed of, a significant proportion of which was to be held on leases in perpetuity. Ballance's village settlement plots made an appearance, but were a resounding failure due to their undesirability as security for capital and a lack of employment in the area - Liberal policy did not provide similar levels of support to diversity in employment as it did to land tenure. ${ }^{113}$ The plots that remained viable long-term were the small farms under McKenzie's lease in perpetuity. ${ }^{114}$ The relative success between the two settlement types illustrates a weakness of both McKenzie in particular and the Liberals in general: an unending focus on the farm as the primary unit of closer settlement, at the expense of adequately supporting other lifestyles within the colony.

Richard Seddon, Ballance's unintended successor as Premier, ${ }^{115}$ promoted the Cheviot settlement promise with enthusiasm in Christchurch during the 1893 election campaign. ${ }^{116}$ The Liberals won every seat in the Canterbury district, the first and last time they did so. All those elected except William Pember Reeves were farmers. Cheviot had resulted in a substantial electoral victory that galvanised support across the country for agrarian rather than urban solutions. ${ }^{117}$ This in turn cemented the promise of "Cheviots to come" as a foundational Liberal policy; ${ }^{118}$ that promise relied primarily upon the continued efforts of McKenzie, but also upon the careful management of Seddon. ${ }^{119}$ Beyond the election, Cheviot was frequently used as a political catch cry. McKenzie leveraged its success to pass the 1894 LFSA introducing compulsion, increasing funding and further reducing parliamentary oversight.

112 At 11 .

113 At $202-205$

114 At $188-189$

115 Hamer, above n 3, at 105-106 and 115; and Tom Brooking Richard Seddon: King of God's Own: The Life and Times of New Zealand's Longest-serving Prime Minister (Penguin Books, Auckland, 2014) at 104-116.

116 Gardner, above n 64 , at $157-158$.

117 Brooking, above n 115, at 133 .

118 Gardner, above n 64, at 159.

119 Brooking, above n 115, at 135 . 
The Land for Settlements Bill 1893 was McKenzie's first attempt to reintroduce compulsory purchase. Again this passed the House, but not the Council. ${ }^{120}$ In 1894, after the "unprecedented" election result and lingering threats to stack the Legislative Council, he was more successful. ${ }^{121}$ Just one Councillor, the perennially anti-McKenzie Robert Pharazyn, spoke against the Bill, throwing every intellectual and biblical argument he could at the policy - including the 10th commandment. ${ }^{122}$ His energetic complaints were to little effect. The Liberals managed to get their compulsory purchase provisions passed into law. ${ }^{123}$ No other jurisdiction in Australasia had such measures for anything other than military emergencies. ${ }^{124}$ It was, without exaggeration, remarkably unique.

In contrast to compulsory purchase, some amendments favoured original proprietors. Fair compensation had always been a feature, but not one that was overly emphasised in promoting the policy. Even before the advent of the 1894 legislation, however, Seddon began to downplay the drastic bursting up rhetoric, preferring to stress fair compensation for landowners. ${ }^{125}$ Provisions enabled owners to, for instance, require the Crown to purchase the entire estate, ${ }^{126}$ retain large areas of land of their choosing, ${ }^{127}$ and stay in possession for nine months (extended to 12 in 1900) following the proclamation of taking. ${ }^{128}$ An amendment Act in 1895 gave original proprietors the right to obtain leases in perpetuity of their homestead and surroundings. ${ }^{129}$ In 1897 , a new provision required the Minister to notify and compensate not only registered proprietors, but also anyone else known to have an interest in the estate. ${ }^{130} 1899$ saw more provisions protecting owners' interests, this time factoring loss of business into compensation calculations, ${ }^{131}$ which in essence gave legislative effect to an earlier judgment of the Compensation Court. ${ }^{132}$ Those who had worked on the land and risked loss of employment through land acquisition could also obtain preferential blocks, as was done amid

120 Brooking, above n 10, at 119.

121 At 127

122 (28 August 1894) 85 NZPD 212-220.

123 Land for Settlements Act 1894, s 6.

124 Brooking, above n 5, at $151 \mathrm{n} 53$.

125 Gardner, above n 64, at 157-158.

126 Land for Settlements Act 1894, s 9.

127 Section 8.

128 Land for Settlements Act 1894, s 19; and Land for Settlements Consolidation Act 1900, s 29.

129 Land for Settlements Amendment Act 1895, s 4.

130 Land for Settlements Amendment Act 1897, s 4.

131 Land for Settlements Amendment Act 1899, s 5.

132 New Zealand and Australian Land Company v Minister of Lands (1895) 13 NZLR 714 (Compensation Court). 
controversy and legal action at Otekaike in $1908 .{ }^{133}$ Generosity to owners and others with an interest in the land expanded considerably in the years following the inaugural LFSA. What might appear to have been radical policy at the expense of owners of large estates had features that were instead decidedly equitable to them, a proposition supported by a great many owners so affected. ${ }^{134}$

It is arguable that closer settlement policy actually benefitted the wealthy by giving them a guaranteed and reliable buyer in uncertain economic times. Despite being subject to more sustained use of the compulsory provisions, land-owning companies that had reluctantly acquired land from foreclosures saw the LFSA as an opportunity to rid themselves of such unwanted assets. ${ }^{135}$ However, it is not clear the times were as strident as sometimes made out: few acquisitions via the LFSA were the result of bankruptcy and much of the land obtained was unburdened by heavy mortgages. ${ }^{136} \mathrm{In}$ addition, there is ample evidence of large estate holders holding out for many years in order to receive higher government offers, ${ }^{137}$ and matching the Government in the amount of private subdivision. ${ }^{138}$ In any event, the LFSA was not generally viewed by the holders of large estates as wholly objectionable.

The policy's main purpose, however, was not forgotten. Recognising the need to back settlers with capital, an 1896 amendment expanded on other legislation in allowing advances to settlers on generous terms. ${ }^{139}$ The focus on ensuring settlement success is evident, too, in the requirement that applicants demonstrate means for meeting improvement conditions imposed in order to combat absenteeism. At the 1904 subdivision at Matamata, for instance, 85 per cent had means over $£ 50,{ }^{140}$ indicating it was settled by "farmers of moderate means and not by struggling land-hungry rural workers". ${ }^{141}$ As an exercise in fairness and equality, the 1908 subdivision of Otekaike is similarly lacking. Although technically landless, all applicants had access to capital ranging from $£ 42$ (somewhat of an outlier) to a considerable $£ 3,200$. In addition, some 23 per cent of the successful

133 Land Laws Amendment Act, 1907, s 80; Mckellar v Land Board of Otago (1908) 27 NZLR 811 (CA); and Bob Hall "Land for the Landless: Settlement of the Otekaike Estate in North Otago 1908" (1985) 19 NZJH 38 at 48.

134 See for example Brooking, above n 10, at 237-238; and Jim McAloon No Idle Rich: The Wealthy in Canterbury and Otago, 1840-1914 (University of Otago Press, Dunedin, 2002) at 134-135.

135 McAloon, above n 134, at 137.

136 At $130-132$.

137 At 132-133; and Hall, above n 133, at 44-45.

138 McAloon, above n 134, at 134-135.

139 Land for Settlements Amendment Act 1896, s 12; and Government Advances to Settlers Act 1894.

140 Brooking, above n 10, at 289.

141 DB Waterson "The Matamata Estate, 1904-1959: Land Transfers and Subdivision in the Waikato" (1969) 3 NZJH 32 at 39. 
applicants were businessmen, rather than labourers or farmers. ${ }^{142}$ Bob Hall summarises the settlement thus: ${ }^{143}$

The intention of the settlement was to break a local instance of landed monopoly and provide land for the landless. This much was successfully achieved, but it has to be borne in mind that the "landless" settlers in question were people with access to some capital, who nevertheless, for the most part did not retain their properties for very long.

The desire to ensure each settler's success resulted in improvement conditions associated with their tenure. To ensure these were met, the LFSA required settlers to demonstrate a minimum access to capital, which effectively excluded a large number of labouring settlers. These conditions necessarily conflict with the rhetoric used to sell the policy to the electorate. The phrase "land for the landless" captured a purity not entirely borne out in practice.

Another feature that illustrates a disconnect between rhetoric and reality is the size of estates bursted up. The Liberals succeeded in bursting up some 223 estates and resettling approximately 1.3 million acres of land. ${ }^{144}$ Studies show the proportion of wealth held by the top one per cent of estates fell from 65 per cent in 1893 to 30 per cent by 1912. ${ }^{145}$ The great estates reduced in number and in size, and the average size of landholdings fell overall. Yet the estates acquired by the Liberals under the LFSA were not predominantly "great". Eighty-three per cent were under 10,000 acres, and almost half were under $1,000 .{ }^{146}$ Barely 13 were above 20,000 acres. ${ }^{147}$ While there were far fewer wealthy families, the policy "never attempted to tear down the top, or to destroy the old élite". ${ }^{148}$ It is difficult, by any measure, to describe this as bursting up the great estates. Perhaps a better characterisation would be a gradual and careful reallocation of the middling estates, but this itself requires the assumption that closer settlement caused rather than complemented broader social change.

The debate between freehold and leasehold never fell away. McKenzie was not endeared to those who continued to object to leases in perpetuity; such complaints, he said, were "largely from men who have taken land under leasehold, been successful, and now want the freehold". ${ }^{149}$ After McKenzie's

142 Hall, above n 133, at 53.

143 At 60.

144 Brooking, above n 10, at 245.

145 Margaret Galt "Wealth and Income in New Zealand c 1870 to 1939 " (PhD thesis, Victoria University of Wellington, 1985) at 24.

146 Brooking, above n 10, at 245-246.

147 At $245-246$.

148 At 256.

149 John McKenzie as cited in Henry Demarest Lloyd Newest England: notes of a democratic traveller in New Zealand, with some Australian Comparisons (Doubleday, New York, 1900) at 140. 
death in 1901, the complaints began to get louder. Seddon, loyal to McKenzie to the end, retorted that freehold advocates wished to "kick away the ladder" that had enabled their own success. ${ }^{150}$ Settlers from Matamata who spoke to the 1905 Royal Commission on Land agitated for freehold over leasehold at a ratio of 23 to one. ${ }^{151}$ Most, particularly those who did not hold sheep runs where freehold would confer little financial gain, wanted to cash-in on rising land values. ${ }^{152}$ Ballance's views of the benefits of nationalising the unearned increment were no longer favoured by the public, if indeed they ever were.

This agitation became louder still after the death of Seddon in 1906. As Hamer observed, due to its origins as a political compromise, the lease in perpetuity found few defenders. ${ }^{153}$ Joseph Ward, seeking to cement his premiership on the back of Seddon's success, sought to end the debate and, in 1907 , leases in perpetuity were dropped altogether in favour of renewable leases with a right of purchase. ${ }^{154}$

Throughout, the Liberals did not ignore the need to address specifically urban issues, although their belief in the superiority of rural living meant for some time they effectively limited themselves to tweaking a policy designed by a farmer for rural land. They sought to increase the number of settlements that might benefit urban workers by allowing smaller areas to be taken near Auckland, Wellington, Christchurch and Dunedin, ${ }^{155}$ and later permitting purchase of smaller lots beyond those four centres. ${ }^{156}$ Such measures were woefully inadequate and formed one of several factors that led to the Liberal's decline, married with the growing dominance of Auckland where the Liberals had struggled to gain support. ${ }^{157}$ The LFSA might be seen as a success for farmers. Yet it did little to alleviate the real and pressing problems in urban centres, whose population generally, much to the Liberals' consternation, showed little interest in actively partaking in the Arcadian dream. ${ }^{158}$ The focus on farming as the panacea to New Zealand's ills might be characterised as a policy designed to

150 Richard Seddon as cited in Hamer, above n 3, at 285. See also Brooking, above n 10, at 224.

151 Royal Commission on Land Tenure and Settlement "Crown Lands: Report of the Royal Commission on LandTenure, Land-Settlement, and Other Matters Affecting the Crown Lands of the Colony" [1905] I AJHR C4A at 984 .

152 Waterson, above n 141, at 41-42.

153 Hamer, above n 3, at 280.

154 At 290; and Land Laws Amendment Act 1907, ss 3-6.

155 Land for Settlements Amendment Act 1897, ss 5 and 8.

156 Land for Settlements Amendment Act 1899, s 6.

157 See Brooking, above n 10, at 265; and Hamer, above n 3, at 177-183, 307 and generally 308-340.

158 Hamer, above n 3, at 68 and 306. 
solve Old World problems while neglecting a thorough assessment of the New World's peculiar context. This is true too, of Liberal considerations of Māori land.

\section{$B$ The Greatest Estate}

A discussion of Liberal settlement policy cannot fail to mention treatment of the Māori estate. Despite reinstating pre-emption ostensibly to protect Māori from unscrupulous purchasers, ${ }^{159}$ the early Liberal era, in contrast to the latter half of the administration, was exceptionally active in appropriating Māori land. The Maori Land Purchase Office under McKenzie was responsible for buying more Māori land at a cheaper price than any other single administration in New Zealand history. ${ }^{160}$ JS Duncan provides a concise comparison: ${ }^{161}$

The Liberal's attack on large freehold estates was one solution to their problem of finding land for their land-hungry supporter; it was largely doctrinaire. The other solution they found was unashamedly expedient: to buy land from the Maoris as quickly and cheaply as possible. The government spent nearly five million pounds between 1893 and 1906 on the purchase of one million acres of freehold land. Over the same period, it spent about $£ 650,000$ on the purchase of some three million acres of Maori land in the North Island.

The disparity in price might, as Duncan suggests, go some way to explain the fact that while the land acquired under the LFSA represented less than one-fifth of the land held in blocks of more than 10,000 acres at the beginning of the Liberal era, in contrast, the amount taken from Māori was several orders of magnitude more in total acreage and represented one-third of the land Māori held at 1891.162

This was not merely a matter of the circumstance that more land belonged to Māori in areas where population pressure was growing. It was a matter of carefully engineered policy. Funding for buying Māori land far exceeded that under the LFSA. ${ }^{163}$ Land retention provisions for owners whose land was subject to acquisition under Māori land legislation allowed only a fraction of what owners could retain under the LFSA and, in addition, Māori could not retain their homesteads. ${ }^{164}$ The presumption that Māori could apply for land under the LFSA was an absurdity: many held land in communal

159 Native Land Court Act 1894, s 117; and (28 September 1894) 86 NZPD 374 per Rt Hon Richard Seddon MHR.

160 Brooking, above n 10, at 133.

161 Duncan, above n 10, at 187.

162 At 188

163 See Robert Stout and AT Ngata "Native Lands and Native Land Tenure (General report on lands already dealt with and covered by interim reports)" [1907] III AJHR G1 at 5; and generally Brooking, above n 10, at 140.

164 Native Land Purchase and Acquisition Act 1893, s 19. Compare Land for Settlements Act 1894, s 8 and definition of "prescribed maximum" in s 2; and Land for Settlements Amendment Act 1895, s 4. 
ownership, which prevented them from falling within the category of landless and thus "bona fide settlers". 165

The Liberal philosophy of "enlightened statism" was not universally subscribed to by Māori; 166 thus James Carroll, like many Māori, opposed the resumption of pre-emption. ${ }^{167}$ Compulsory purchase as per the LFSA did not feature in Māori land legislation. Nevertheless sales were often, to put it mildly, extremely reluctant. Māori Members of the House repeatedly invoked the parable of King Ahab, whose Queen Jezebel nefariously orchestrated the death of Naboth after he had refused to sell his vineyard to Ahab, ${ }^{168}$ a strategy the Māori Members shared somewhat incongruously with Legislative Councillor Pharazyn. ${ }^{169}$

Aside from what Brooking calls the "simple [reasons] ... of greed, racism and political expediency", underlying these and many other discriminatory legislative provisions was the principle of utility. ${ }^{170}$ The best claims to land were those of farmers who used the land efficiently. Māori land was often criticised as a wasted, unproductive wilderness and Liberal policy sought to change this for the benefit of productive settlers. As he was introducing the Native Land Purchase and Acquisition Act 1893, McKenzie warned: ${ }^{171}$

The time has come, when the Natives must be called upon to make up their minds as to whether they would make good use of their land, or allow use to be made of it by the government.

And yet, the Advances for Settlers scheme, which afforded low-cost loans to those who took up and improved land, excluded Māori almost entirely. ${ }^{172}$

This significant disparity evokes a question: did the Liberals exploit the LFSA as convenient veil for their real target? Perhaps not. Certainly differing approaches were taken in the South and North Islands, designed to address specific problems. Māori landlordism, land underutilisation and "communistic" ownership were considered as evil as the land banking of South Island gentry. Liberal

165 Brooking, above n 10, at 153.

166 Boast, above n 11, at 192 .

167 Commission on Native Land Laws "Report of the Commission Appointed to Inquire into the Subject of the Native Land Laws" [1891] II AJHR G1 at xxviii. See also Boast, above n 11, at 186-195.

168 See for example (5 September 1893) 81 NZPD 521 per Eparaima Te Mutu Kapa MHR. See also Brooking, above $\mathrm{n} 11$, at 90 .

169 (28 August 1894) 85 NZPD 212-220.

170 Brooking, above n 10, at 144. For examples of other provisions see Brooking, above n 11.

171 (5 September 1893) 81 NZPD 512-513.

172 Government Advances for Settlers Act 1894. See also Brooking, above n 10, at 141; and Boast, above n 11, at 260 . 
policy relating to Māori land was conceived in terms "consistent with their aims of promoting closer settlement, revitalising rural communities, filling empty spaces with people and sharing property, wealth and power more evenly". ${ }^{173}$

Propositions that McKenzie's motivations were more honourable than those of previous politicians are supported by few Liberals benefitting personally from the new wash of Māori land. ${ }^{174}$ Indeed, they legislated to prevent "swindling" by one Legislative Councillor. ${ }^{175}$ Despite this, the Liberals simply cannot escape the fact that during McKenzie's time as Minister, a devastating amount of land was extracted from Māori. Brooking notes the double irony in Liberal treatment of Māori land: ${ }^{176}$

First, in attempting to ensure that the horrors of the highland clearances were not repeated in New Zealand

John McKenzie effectively dispossessed Maori. Second ... Liberal purchase of so much Maori land for

so little money widened the fracture in the New Zealand dream, a fracture which has yet to be healed.

Pākehā owners of the great estates were treated as they were to ensure they were not alienated from political systems of the wider community. Compulsion, for instance, was used sparingly. ${ }^{177}$ In contrast, the Māori population had diminished, a trend believed to be irreversible. ${ }^{178}$ Consequently, Māori were progressively excluded. Liberal land policy regarding the greatest estate represents a paradox: many Māori were left in much the same position as those 90 people McKenzie had seen during the Highland Clearances. The deep tragedy remains that in focusing on perceptions of the Old World and "imposing their own modest dreams upon another people the Liberals lost an opportunity for the development of a truly bicultural society", ${ }^{179}$ and indeed, one that was genuinely uniformly fair.

\section{AN IDEOLOGY IN CONCLUSION}

When pride cometh, then cometh shame: but with the lowly is wisdom. ${ }^{180}$

With the aim of making good on Arcadian visions of New Zealand, the Liberals responded to the land question with more than mere rhetoric. Ballance and McKenzie, both in their own ways absorbed

173 Brooking, above n 10, at 154 .

174 At 154

175 Native Land Laws Amendment Act 1897. See also Brooking, above n 11, at 97.

176 Brooking, above n 11 , at 98.

177 Hamer, above n 3, at 143.

178 Boast, above n 11, at 185 .

179 Brooking, above n 11, at 97.

180 Proverbs 11:2. 
by Old World land problems, inaugurated complex legislation in order to both softly encourage and bluntly force the breaking up of large estates for the benefit of a greater number of settlers.

These policies looked radical, but were in fact used rather sensitively. They were tempered by the practicalities of farming and a desire to be fair to both sides of the equation. The estates themselves were more often than not selected with care and thus varied significantly in size, with the majority falling far below what one might call great. Compulsion, the most radical feature, was infrequently invoked.

More equal wealth distribution was generally achieved. Great estates were reduced in number and in size; more people were on more plots of land. Yet whether the Liberal closer settlement policy is solely responsible for this remains questionable. Private subdivision accounts for at least as much as that settled under the LSFA. Moreover, the quantity of LFSA land is dwarfed by that taken and distributed under Māori land legislation.

Liberal attitudes to Māori land is a lingering point of discordance. A combination of strict rules and compulsion was tempered with generosity and fairness when it came to Pākehā landowners and settlers, but not when it came to Māori. Addressing urban concerns directly, rather than as a trickle down benefactor of rural closer settlement, was also neglected. McKenzie may have "died confident that he had made it impossible for white settlers to experience any repeat of the Highland Clearances", ${ }^{181}$ but in the case of Māori land and urban issues, it appears he was fighting an Old World battle at the expense of important attributes of the New World context.

Liberal politicians each had their failings and yet together they offered significant contributions to New Zealand's idea of itself. With varying degrees of conviction, they embarked on some of the most cherished legislative reform in New Zealand history: women's suffrage, the Queen's chain, union and arbitration legislation, old age pensions and penny postage to name a few. Land policy, too, had lasting effect. In their concern for reducing inequality of land ownership, the Liberals did not seek to eradicate the gentry altogether nor remove them from public life. As Brooking and Fairburn have noted, however, politics remained dominated by farmers and working men for the next generation. ${ }^{182}$ Thus, despite finally losing their grip on power in 1912, the Liberals might lay claim to influencing the character of parliamentary representatives, and thus the character of the debate, for many years beyond.

In the context of land, the colonial reality may not have met the Arcadian promise, but the Liberals developed a rhetoric that has retained significance in New Zealand politics and society ever since. The Liberals' triumphing of the concept of the family farm contributed to its continued strength, albeit

181 Brooking, above n 10, at 130.

182 Brooking, above n 10, at 256; and Miles Fairburn "The Farmers Take Over, 1912-1930" in Keith Sinclair (ed) The Oxford Illustrated History of New Zealand (Oxford University Press, Auckland, 1990) 185. 
perhaps now existing primarily in the New Zealand mentality rather than reality. Likewise, while putting aside the particular arguments of freehold versus leasehold, the rhetoric of fairness, independence and stability would not appear out of place in the mouths of politicians today. Land, and access to it, remains a highly contested issue.

What David Hackett Fischer calls New Zealand's "tradition of fairness ... was not a simple story of continuity but a complex process of invention and rejection, achievement and failure ... transformation and revival". ${ }^{183}$ Deep-seated pride in the settler dream carried with it inherent risks of overlooking essential particularities of context, leading to disparate outcomes. Yet closer settlement and its failings are part of a tradition that suggests, in the words of Brooking, that New Zealand was "a rather unusual place". ${ }^{184}$ As New Zealand continues to negotiate the effects of Liberal land policy and its ideologies, so too it remains.

183 Fischer, above n 6, at 169.

184 Brooking, above n 5, at n 53. 